\title{
Manifestaciones Orales Relacionadas con la COVID-19
}

\author{
Oral manifestations related to COVID-19
}

\author{
Yaimeé Guerrero Díaz
}

GUERRERO, D. Y. Manifestaciones orales relacionadas con la COVID-19. Int. J. Odontostomat., 15(2):307-308, 2021.

\section{Sr. Editor:}

Las manifestaciones orales de la COVID-19 en la salud oral están principalmente determinadas por el sistema inmunológico del paciente, la farmacoterapia a la que está sometido y por la patogenia del virus. Se ha sugerido que la cavidad oral es un perfecto hábitat para el SARS-CoV-2 debido a la especial afinidad que tiene el virus por células del tracto respiratorio y mucosa oral. Se ha evidenciado que este coronavirus tiene afinidad con los receptores del ácido siálico, el cual es un componente fundamental de la mucina salival que protege las glucoproteínas que transmiten moléculas gustativas dentro de los poros gustativos durante el proceso de la digestión. De esta manera, el SARS-CoV-2 podría ocupar los sitios de unión del ácido siálico en las papilas gustativas, provocando pérdida de la percepción del gusto. Esta alteración provocada por el SARS-CoV-2 podría explicar la pérdida del gusto descrita frecuentemente en pacientes positivos a la enfermedad, que puede durar días, semanas e incluso meses y su mejora dependerá de la resolución de los síntomas clínicos generales propios de COVID-19 (Vaira et al., 2020).

La cavidad oral es un reservorio de patógenos del sistema respiratorio, por este motivo, los pacientes con enfermedad periodontal tienen mayor posibilidad de desarrollar un cuadro de neumonía. Además, se sabe que en la mucosa oral existen receptores enzima convertidora de angiotensina 2 (ACE-2 por sus siglas en inglés), los cuales son la puerta de entrada para este nuevo virus (Soares et al., 2020).

Entre las alteraciones descritas por estudios recientes se encuentran lesiones ulcerativas de color naranja y amarillentas puntiformes con halo eritema- toso y distribución simétrica en el paladar duro (ChauxBodard et al., 2020); lesiones ulcerativas de patrón irregular al dorso de la lengua en paciente positiva al test rápido asintomática, también se ha hecho referencia a la presencia de petequias milimétricas sin eritema en paladar duro y blando descritas en pacientes positivos para COVID-19 (Soares et al.).

Estudios sugieren que los sacos periodontales podrían ser entornos compatibles para la infección viral y supervivencia del SARS-CoV-2. De igual forma, células inmunes contagiadas con el virus podrían desplazarse al tejido conectivo y migrar al área subgingival, provocando el desarrollo de Gingivitis Úlceronecrotizante Aguda descrita en pacientes con diagnóstico de periodontitis en casos severos de COVID19 , probablemente, debido a un estado inflamatorio persistente que podría actuar como desencadenante en la cascada de la coagulación y asociarse con el incremento de niveles de productos de degradación de fibrinógeno (Patel \& Woolley, 2021).

Un estudio recientemente publicado en Londres hace referencia a la lengua COVID" características de la lengua de pacientes con enfermedad por coronavirus que presentan aumento de volumen y zonas depapiladas en parches, señalando que varios pacientes con COVID-19 leve y moderado comúnmente presentaban lengua de color rojo pálido alternando con zonas blancas. Pacientes con síntomas graves suelen presentar la lengua saburral. Sin embargo, el estudio precisa que aún se necesitarían más investigaciones para mejorar la cuantificación de las características de la lengua COVID, por lo que no es concluyente su relación con la COVID-19 (Díaz Rodríguez et al., 2020). 
Se han descrito lesiones orales relacionadas con esta enfermedad, por lo que debemos perfeccionar nuestros conocimientos y promover la salud de la cavidad oral.

\section{REFERENCIAS BIBLIOGRÁFICAS}

Vaira, L. A.; Salzano, G.; Fois, A. G.; Piombino, P. \& De Riu, G. Potential pathogenesis of ageusia and anosmia in COVID-19 patients. Int. Forum Allergy Rhinol., 10(9):1103-4, 2020.

Soares, C. D.; Carvalho, R. A.; Carvalho, K. A.; Carvalho, M. G. \& Almeida, O. P. Letter to Editor: Oral lesions in a patient with Covid19. Med. Oral Patol. Oral Cir. Bucal, 25(4):e563-4, 2020.

Chaux-Bodard, A. G.; Deneuve, S. \& Desoutter, A. Oral manifestation of Covid-19 as an inaugural symptom? J. Oral Med. Oral Surg., 26(2):18, 2020.

Patel, J. \& Woolley, J. Necrotizing periodontal disease: Oral manifestation of COVID-19. Oral Dis., 27 Suppl. 3:768-9, 2021.

Díaz Rodríguez, M.; Jiménez Romera, A. \& Villarroel, M. Oral manifestations associated with COVID-19. Oral Dis., 2020. DOI: https://www.doi.org/10.1111/odi.13555
Dirección para correspondencia:

Yaimeé Guerrero Día

Universidad de Ciencias Médicas de Holguín

Facultad de Ciencias Médicas

"Mariana Grajales Coello"

Departamento de Estomatología General Integral

Holguín

CUBA

E-mail: yaimee3993@gmail.com

ORCID: 0000-0002-9641-187X 